\title{
ANALISIS POLARIMETRI ALOS 1 PALSAR UNTUK ZONASI MINERAL ALTERASI HIDROTERMAL DI KABUPATEN SOPPENG SULAWESI SELATAN
}

\author{
ANALYSIS OF ALOS-1 PALSAR POLARIMETRY FOR MINERAL \\ ALTERATION ZONE IN SOPPENG REGENCY SULAWESI SELATAN \\ ${ }^{1}$ Anugerah Ramadhian AP, Retnadi Heru Jatmiko ${ }^{2 *}$, dan Wirastuti Widyatmanti ${ }^{3}$ \\ Penginderaan Jauh, Fakultas Geografi \\ Universitas Gadjah Mada \\ Email: anugerahramadhianap@gmail.com
}

Submitted: 30-10-2019; Revised: 11-01-2021; Accepted: 27-01-2020

\begin{abstract}
Radar technology in remote sensing can be used for a variety of mapping, such as geological mapping. Soppeng Regency, South Sulawesi has a complex geological condition characterized by structural and intrusion phenomena with old materials. The phenomenon is an indicator of hydrothermal alteration due to magma intrusion activity in the rock bedding. Radar imagery is able to identify hydrothermal alteration zones through physical approaches such as landforms, rock (lithology), and geological structures. The aim of this research to explore the ability of radar polarization to identify hydrothermal alteration parameters and distribution pattern in Soppeng Regency. The physical characteristics are obtained from visual interpretation of the ALOS-1 PALSAR multi-polarization imagery with terrain analysis approach. Sample data is needed for petrographic analysis to determine rock minerals content. Analysis of physical characteristics and petrographic analysis were used to determine the type and distribution of hydrothermal alteration zones. The result of this study are ALOS-1 PALSAR imagery can be used to produce information on landform, rocks (lithology), and geological structures with total accuracy 83,9\%. The hydrothermal alteration zone in Soppeng Regency consists of argillic 221,662 $\mathrm{km}^{2}$, advanced argillic 20,239 $\mathrm{km}^{2}$, phyllic $94,790 \mathrm{~km}^{2}$, potassic $46,678 \mathrm{~km}^{2}$, propylitic 328,746 $\mathrm{km}^{2}$, sub-propylitic 181,517 $\mathrm{km}^{2}$, and skarn $75,635 \mathrm{~km}^{2}$.
\end{abstract}

Keywords: Hydrothermal Alteration; Multi-Polarization; Radar Imagery; Remote Sensing; Visual Interpretation

\section{ABSTRAK}

Perkembangan teknologi penginderaan jauh radar dapat digunakan untuk berbagai macam pemetaan, salah satunya pemetaan informasi geologi. Kabupaten Soppeng Sulawesi Selatan memiliki kondisi geologi kompleks ditandai dengan adanya kontrol struktur dan fenomena intrusi dengan material batuan yang memiliki umur geologi tua. Fenomena tersebut merupakan indikator adanya mineral alterasi hidrotermal karena adanya aktivitas intrusi magma pada bidang pelapisan batuan. Penginderaan jauh radar mampu untuk mengidentifikasi mineral alterasi hidrotermal melalui pendekatan fisik

*Corresponding author: retnadih@ugm.ac.id

Copyright @ 2020 THE AUTHOR(S). This article is distributed under a Creative Commons Attribution-Share Alike 4.0 International license. Jurnal Teknosains is published by the Graduate School of Universitas Gadjah Mada. 
medan seperti bentuk lahan, batuan (litologi), dan struktur geologi. Tujuan dari penelitian ini yaitu mengetahui kemampuan polarimetri radar untuk identifikasi parameter mineral alterasi hidrotermal dan pola persebarannya di Kabupaten Soppeng. Karakteristik fisik medan diperoleh dari interpretasi visual citra ALOS-1 PALSAR multipolarisasi. Data sampel diperlukan untuk analisis mineral dan petrografi sehingga mengetahui kandungan mineral batuan. Analisis karakteristik fisik medan dan hasil analisis mineral petrografi digunakan untuk menentukan tipe dan sebaran mineral alterasi hidrotermal. Hasil penelitian menunjukkan bahwa citra ALOS-1 PALSAR HH, $\mathrm{HV}, \mathrm{HV}$ dapat menghasilkan informasi parameter bentuk lahan, batuan (litologi), dan struktur geologi dengan baik ditandai dengan nilai total akurasi $83,9 \%$. Zona mineral alterasi hidrotermal di Kabupaten Soppeng terdiri dari zona alterasi argilik 221,662 km², argilik sempurna $20,239 \mathrm{~km}^{2}$, filik $94,790 \mathrm{~km}^{2}$, potasik $46,678 \mathrm{~km}^{2}$, propilitik $328,746 \mathrm{~km}^{2}$, sub propilitik $181,517 \mathrm{~km}^{2}$, dan skarn $75,635 \mathrm{~km}^{2}$.

Kata Kunci: Alterasi Hidrotermal; MultiPolarisasi, Citra Radar, Penginderaan Jauh, Interpretasi Visual

\section{PENGANTAR}

Sumber daya alam merupakan aspek penting bagi suatu negara terutama pada negara berkembang seperti Indonesia. Besarnya potensi sumber daya alam dipengaruhi oleh banyak faktor, salah satunya yaitu proses pembentukan daratan. Indonesia terletak pada tiga zona tumbukan lempeng samudera dan benua aktif yaitu lempeng eurasia, pasifik, dan indo-australi (Verstappen, 2000). Fenomena tersebut berdampak besar terhadap potensi sumber daya alam yang ada di dalamnya. Menurut PP No. 23 Pasal 2 Ayat 2 Tahun 2010 salah satu sumber daya alam non hayati yaitu sumber daya alam bahan galian yang dibedakan menjadi sumber daya mineral logam dan non-logam. Sumber daya tersebut dipengaruhi oleh tingkat kompleksitas geologi yang menentukan terbentuknya mineralmineral pada suatu wilayah (Carranza, 2002).

Kabupaten Soppeng Provinsi Sulawesi Selatan merupakan salah satu kabupaten dengan fenomena geologi yang kompleks.
Kompleksitas fenomena geologi tersebut ditandai dengan adanya kontrol struktur geologi yang kuat dengan umur material batuan tersier eosen hingga pliosen. Selain itu banyaknya fenomena intrusi menambah tingkat kompleksitas geologi di dalamnya. Aktivitas magma menerobos pelapisan batuan menyebabkan adanya perubahan unsur fisik dan kimia mineral batuan yang sering disebut dengan mineral teralterasi. Fenomena tersebut menjadi ciri adanya potensi sumber daya mineral di Kabupaten Soppeng terutama mineral teralterasi hidrotermal.

Penginderaan jauh menjadi salah satu teknik yang digunakan untuk menghasilkan informasi permukaan bumi dengan menggunakan bantuan citra mengalami banyak perkembangan salah satunya untuk identifikasi zona mineral alterasi hidrotermal. Penggunaan data radar ALOS-1 PALSAR dapat menghasilkan informasi karakteristik fisik medan meliputi kondisi bentuk lahan, batuan (litologi), dan struktur geologi yang menjadi ciri adanya mineral teralterasi hidrotermal. Menurut Ulaby dkk. (1986), Spatz (1997), dan Zandbergen (2008) penggunaan saluran panjang gelombang radar band $\mathrm{C}$ dan $\mathrm{L}$ cocok digunakan untuk analisis geologi karena kemampuan penetrasi yang baik di permukaan bumi. Begitu juga dengan Pour dan Hashim (2014) menggunakan data radar ALOS-1 PALSAR untuk analisis struktur geologi dan menghasilkan informasi struktur geologi yang baik.

Identifikasi mineral alterasi hidrotermal menggunakan data ALOS1 PALSAR biasa dilakukan dengan satu polarisasi $\mathrm{HH}$ atau HV. Penggunaan kombinasi polarisasi (multi-polarisasi) dapat dilakukan untuk meningkatkan kemampuan data radar dalam identifikasi mineral alterasi hidrotermal. Perbedaan 
cara pengiriman dan penerimaan pulsa radar akan memberikan informasi yang berbeda fenomena objek permukaan bumi. Tujuan dari penelitian ini adalah mengetahui kemampuan radar ALOS-1 PALSAR multi-polarisasi untuk identifikasi parameter mineral alterasi hidrotermal dan mengetahui persebaran zona mineral alterasi hidrotermal di daerah penelitian.

\section{Metode \\ Lokasi Penelitian}

Penelitian ini berada di Kabupaten Soppeng Provinsi Sulawesi Selatan dengan letak geografis $4^{\circ} 6^{\prime} 00^{\prime \prime}$ - $4^{\circ} 32^{\prime} 00^{\prime \prime}$ Lintang Selatan dan $119^{\circ} 47^{\prime} 18^{\prime \prime}$ - $120^{\circ} 06^{\prime} 13^{\prime \prime}$ Bujur Timur.

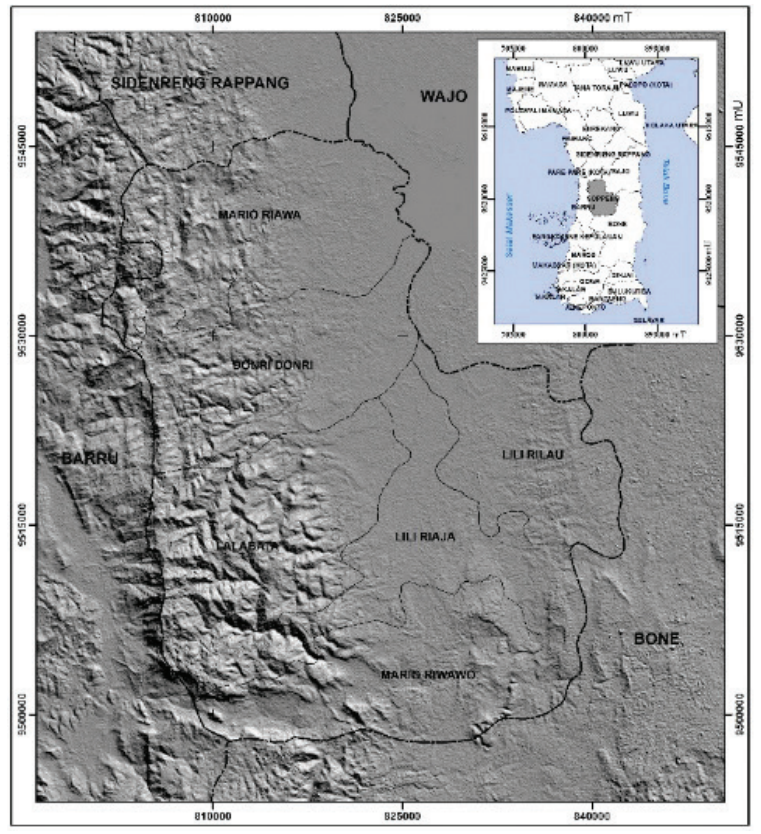

Gambar 1.

Lokasi Penelitian

Sumber: Analisis dan Pengolahan Citra Digital

(2019)

\section{Alat dan Bahan}

Alat yang digunakan dalam penelitian ini adalah komputer, perangkat lunak SNAP 5.0.0, ENVI 5, ArcGIS 10.4, Microsoft Office 365, palu geologi, Global Positioning System (GPS), dan kompas geologi. Bahan dalam penelitian ini adalah citra radar ALOS-1 PALSAR polarisasi ganda $\mathrm{HH}$ dan $\mathrm{HV}$ perekaman 09-09-2008 path 412 frame 7090 dan 7100, Peta Rupa Bumi Indonesia Digital skala 1:50.000, Peta Geologi Lembar Pangkajene - Watampone skala 1:250.000.

\section{Kalibrasi}

Proses kalibrasi data radar dilakukan untuk memperbaiki kualitas pixel data radar. Proses ini dilakukan dengan menggunakan algoritma dari desain sistem dan analisis data radar. Nilai gain dan phase harus sesuai dengan nilai backscatter yang diperoleh dari perekaman permukaan bumi.

\section{Filtering}

Filtering dilakukan pada data radar untuk mengurangi gangguan saat perekaman citra. Banyaknya gangguan menyebabkan data radar sulit untuk mengenali informasi permukaan bumi. Filter median 5x5 digunakan untuk menghasilkan visualisasi yang baik pada data radar dan informasi permukaan bumi terlihat jelas dan detail.

\section{Koreksi Geometrik}

Koreksi geometrik data radar digunakan untuk menghasilkan data radar yang memiliki posisi atau koordinat yang sesuai dengan permukaan bumi. Data radar yang direkam belum memiliki koordinat yang sesuai dengan permukaan bumi sehingga perlu untuk dilakukan koreksi. Proses koreksi dilakukan dengan menggunakan metode image to image geo-correction yaitu koreksi geometrik menggunakan citra lain yang memiliki koordinat sesuai di permukaan bumi seperti data SRTM.

\section{Mosaik}

Perekaman data radar dilakukan secara bertahap dan menghasilkan scene citra radar. Penelitian ini menggunakan dua scene citra radar sehingga perlu dilakukan proses mosaik citra. Mosaik citra penting dilakukan untuk menggabungkan citra yang terpisah 
perekamannya menjadi satu citra baru yang selanjutnya dapat di proses lebih jauh. Proses ini dilakukan menggunakan mozaic georeferenced yaitu dengan penggabungan scene citra yang memiliki posisi atau koordinat yang berimpitan sehingga dapat dilakukan proses penggabungan.

\section{Multi-polarisasi}

Proses perekaman data radar dilakukan dengan dua polarisasi yaitu $\mathrm{HH}$ dan $\mathrm{HV}$. Setiap polarisasi memiliki visualisasi citra yang berbeda tergantung dari respons objek permukaan bumi dengan sinyal radar yang dikirimkan. Akibatnya dua polarisasi yang berbeda memiliki informasi yang berbeda pada data radar. Untuk menghasilkan informasi permukaan bumi lebih baik dan jelas maka proses multi-polarisasi diperlukan dengan cara menggabungkan dua polarisasi tersebut ke dalam ruang warna Red (R), Green (G), dan Blue (B) menghasilkan data baru dengan kombinasi polarisasi tersebut. Penggabungan polarisasi mampu menghasilkan visualisasi data radar dengan baik dan jelas untuk identifikasi informasi permukaan bumi.

\section{Analisis Data Radar}

Analisis data dilakukan dengan beberapa tahapan yaitu interpretasi bentuk lahan, interpretasi batuan (litologi), interpretasi struktur geologi, dan analisis mineral petrografi. Interpretasi bentuk lahan dilakukan dengan melihat kondisi topografi, pola aliran, dan kerapatan aliran. Berdasarkan ketiga pendekatan tersebut maka dapat menunjukkan informasi perbedaan proses, intensitas proses, dan material dasar penyusun bentuk lahan sehingga dapat menentukan jenis bentuk lahan. Interpretasi batuan (litologi) dilakukan dengan melihat bentuk lahan, kondisi topografi, dan intensitas proses yang bekerja. Struktur geologi dapat dikenali dengan adanya polapola kelurusan, perbedaan kondisi topografi secara tegas, dan pola aliran. Analisis mineral dan petrografi dilakukan dengan cara uji sampel batuan untuk menghasilkan informasi komposisi dan jenis mineral penyerta pada sampel batuan yang di ambil.

\section{Uji Akurasi}

Uji akurasi dilakukan untuk mengetahui kemampuan citra radar dalam menghasilkan informasi parameter mineral alterasi hidrotermal yaitu bentuk lahan, batuan (litologi), dan struktur geologi. Uji akurasi dilakukan dengan menggunakan confusion matrix yaitu penilaian akurasi berdasarkan hasil interpretasi dengan kondisi sebenarnya di lapangan menggunakan matriks kesalahan. Penilaian ini dilakukan berdasarkan kecocokan variabel hasil interpretasi citra dengan kondisi di lapangan atau data yang dianggap benar seperti peta geologi.

\section{HASIL DAN PEMBAHASAN Radar Multi-Polarisasi}

Multi-polarisasi data radar ALOS-1 PALSAR digunakan untuk menghasilkan visualisasi citra yang paling baik untuk melakukan identifikasi parameter bentuk lahan, batuan (litologi), dan struktur geologi. Data radar ALOS-1 PALSAR polarisasi $\mathrm{HH}$ dan HV digunakan sebagai input dan menghasilkan enam kombinasi saluran seperti pada Gambar 2. Data radar greyscale diubah ke dalam ruang warna RGB sehingga menghasilkan citra baru dengan visualisasi lebih baik. Multi-polarisasi $\mathrm{HH}(\mathrm{R}), \mathrm{HV}(\mathrm{G}), \mathrm{HV}$ (B) dapat menggambarkan kondisi topografi dengan baik dan jelas sehingga untuk identifikasi parameter bentuk lahan, batuan (litologi), dan struktur geologi dapat dilakukan dengan baik. Adanya batas perubahan kondisi topografi terlihat sangat jelas antara daerah dengan kondisi topografi datar hingga berbukit atau bergunung. Informasi ini sangat penting untuk menentukan parameter bentuk lahan dan batuan (litologi). Selain perbedaan kondisi topografi yang sangat jelas, adanya pola-pola kelurusan, perubahan kemiringan lereng yang sangat tegas, dan pola lipatan dapat dikenali dengan baik. Informasi ini sangat penting untuk penentuan parameter struktur geologi di Kabupaten Soppeng. 

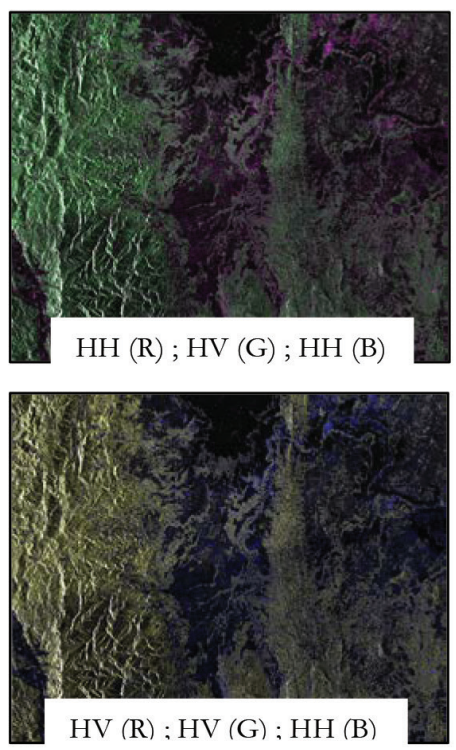

HV (R) ; HV (G) ; HH (B)
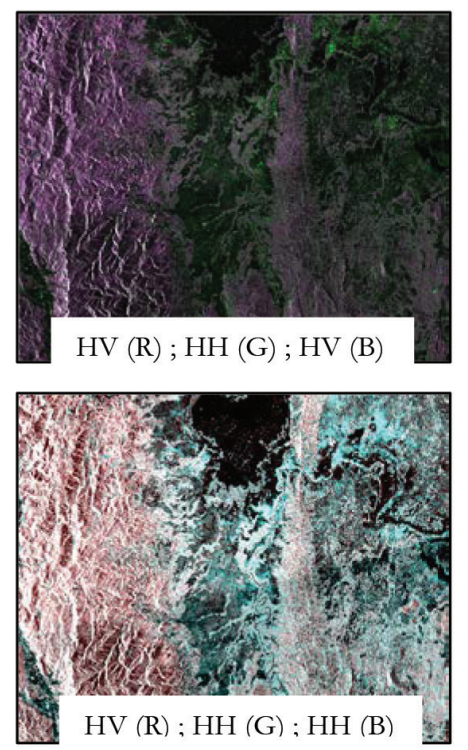

Gambar 2.
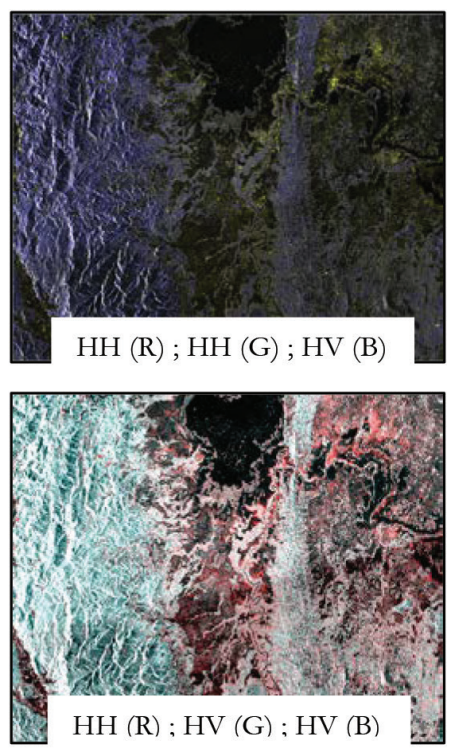

Perbandingan Kombinasi Polarisasi ALOS-1 PALSAR

Sumber: Analisis dan Pengolahan Citra Digital, 2019

\section{Bentuk Lahan Daerah Penelitian}

Penentuan betuklahan dilakukan dengan cara interpretasi visual citra ALOS-1 PALSAR multi-polarisasi $\mathrm{HH}, \mathrm{HV}, \mathrm{HV}$. Penamaan bentuk lahan di dasarkan pada kondisi topografi, umur, intensitas proses, dan material utama penyusun bentuk lahan. Kondisi topografi sangat berpengaruh terhadap bentuk lahan yang dibentuk. Berbeda kondisi topografi maka berbeda juga bentuk lahan yang dihasilkan karena proses yang bekerja pada masingmasing kondisi topografi berbeda. Umur geologi juga sangat berpengaruh terhadap informasi bentuk lahan yang dihasilkan karena terkait dengan umur material penyusun bentuk lahan. Pada material dengan umur geologi tua maka proses erosi dan denudasi akan lebih dominan karena material lebih lapuk dibandingkan dengan material dengan umur geologi lebih muda. Hal itu menyebabkan berbedanya hasil pembentukan bentuk lahan di suatu wilayah. Intensitas proses yang bekerja pada suatu material dapat menjadi ciri utama penentuan bentuk lahan di suatu wilayah. Tingginya intensitas proses yang bekerja akan menyebabkan material penyusun bentuk lahan mengalami proses erosi yang sangat kuat sehingga membentuk daerah-daerah dengan kondisi topografi berbukit hingga bergunung dengan material batuan resisten. Berbeda dengan daerah yang memiliki intensitas proses rendah atau lemah, pada kondisi tersebut maka proses sedimentasi lebih dominan dibandingkan dengan proses erosi. Akibatnya, bentuk lahan yang dihasilkan akan memiliki kondisi topografi datar hingga landai karena banyaknya material yang menumpuk disebabkan oleh proses sedimentasi. Material penyusun pada suatu bentuk lahan juga menjadi ciri utama dalam penentuan bentuk lahan di suatu wilayah. Berbeda material penyusun maka berbeda pula bentuk lahan yang terbentuk. Pada daerah dengan material batuan beku akan membentuk bentuk lahan asal proses vulkanik karena jenis material batuan beku dihasilkan dari proses gunung api. Berbeda dengan material batuan sedimen yang akan membentuk bentuk lahan asal proses fluvial karena proses sedimentasi material-material oleh sungai. Oleh karena itu, penggabungan keempat informasi tersebut mampu menunjukkan satuan bentuk lahan yang terbentuk pada suatu daerah dengan mudah dan baik. Berdasarkan hasil interpretasi visual yang dilakukan, terdapat lima satuan bentuk lahan yaitu vulkanik, struktural, denudasi, solusional (karst), dan fluvial yang disusun oleh 26 sub-satuan bentuk lahan seperti pada Tabel 1 . 
Tabel 1

Sub Satuan Bentuk Lahan dan Luasan Hasil Interpretasi

\begin{tabular}{|c|c|c|}
\hline Kode & Bentuk lahan & Luas $\left(\mathrm{Km}^{2}\right)$ \\
\hline F1 & Dataran Aluvial Berbatuan Kerikil, Pasir dan Lempung & 393.193 \\
\hline V1 & Bukit Intrusi Berbatuan Trakit & 2.803 \\
\hline $\mathrm{V} 11 / 3$ & Bukit Gunung api Tua Terdenudasi Kuat Berbatuan Breksi & 124.769 \\
\hline V17/3 & $\begin{array}{l}\text { Lembah Antar Bukit Gunung Api Tua Terdenudasi Kuat Berbatuan Batu } \\
\text { Pasir dan Batu Lempung }\end{array}$ & 23.851 \\
\hline $\mathrm{V} 11 / 1$ & Bukit Gunung Api Tua Terdenudasi Lemah Berbatuan Breksi & 87.802 \\
\hline $\mathrm{V} 11 / 2$ & Bukit Gunung Api Tua Terdenudasi Sedang Berbatuan Lava & 62.928 \\
\hline $\mathrm{V} 11 / 3$ & $\begin{array}{l}\text { Bukit Gunung Api Tua Terdenudasi Kuat Berbatuan Lava, Breksi dan } \\
\text { Sisipan Tuff }\end{array}$ & 26.606 \\
\hline $\mathrm{V} 11 / 3$ & Bukit Gunung Api Tua Terdenudasi Kuat Berbatuan Lava dan Breksi & 44.656 \\
\hline $\mathrm{V} 11 / 3$ & Bukit Gunung Api Tua Terdenudasi Kuat Berbatuan Lava & 47.384 \\
\hline $\mathrm{V} 11 / 2$ & Bukit Gunung Api Tua Terdenudasi Sedang Berbatuan Lava dan Breksi & 32.657 \\
\hline $\mathrm{V} 11 / 2$ & Bukit Gunung Api Tua Terdenudasi Sedang Berbatuan Breksi & 40.416 \\
\hline D3 & Bukit Sisa Berbatuan Batu Pasir & 6.234 \\
\hline $\mathrm{S} 5 / 3$ & $\begin{array}{l}\text { Perbukitan Antiklinal Terkikis Kuat Berbatuan Batu Gamping dan Batu } \\
\text { Lempung }\end{array}$ & 6.503 \\
\hline S21 & Perbukitan Struktural Berbatuan Batu Lempung dan Batu Lanau & 31.222 \\
\hline S22 & Lembah Antar Perbukitan Berbatuan Batu Pasir dan Batu Lempung & 11.480 \\
\hline $\mathrm{S} 5 / 2$ & $\begin{array}{l}\text { Perbukitan Antiklinal Terkikis Sedang Berbatuan Batu Gamping dan Batu } \\
\text { Lempung }\end{array}$ & 21.712 \\
\hline $\mathrm{V} 11 / 2$ & $\begin{array}{l}\text { Bukit Gunung Api Tua Terdenudasi Sedang Berbatuan Lava, Breksi dan } \\
\text { Sisipan Tuff }\end{array}$ & 86.920 \\
\hline K2 & Perbukitan Karst Terkikis Berbatuan Batu Gamping dan Napal & 75.635 \\
\hline S23 & Lereng Kaki Perbukitan Antiklinal Berbatuan Batu Lempung dan tufa & 30.287 \\
\hline S5/1 & $\begin{array}{l}\text { Perbukitan Antiklinal Terkikis Lemah Berbatuan Batu Lempung dan Batu } \\
\text { Lanau }\end{array}$ & 81.954 \\
\hline $\mathrm{V} 16 / 2$ & $\begin{array}{l}\text { Lereng Kaki Bukit Gunung Api Tua Terdenudasi Sedang Berbatuan Breksi } \\
\text { dan Konglomerat }\end{array}$ & 47.229 \\
\hline $\mathrm{V} 16 / 3$ & Lereng Kaki Bukit Gunung Api Tua Terdenudasi Kuat Berbatuan Breksi & 7.661 \\
\hline V16/1 & $\begin{array}{l}\text { Lereng Kaki Bukit Gunung Api Tua Terdenudasi Lemah Berbatuan Breksi } \\
\text { dan Konglomerat }\end{array}$ & 27.844 \\
\hline $\mathrm{V} 16 / 1$ & Lereng Kaki Bukit Gunung Api Tua Terdenudasi Lemah Berbatuan Breksi & 12.056 \\
\hline V16/3 & $\begin{array}{l}\text { Lereng Kaki Bukit Gunung Api Tua Terdenudasi Kuat Berbatuan Breksi } \\
\text { dan Konglomerat }\end{array}$ & 20.239 \\
\hline F3 & Danau & 8.329 \\
\hline Total & & 1362.372 \\
\hline
\end{tabular}

Sumber: Analisis dan Pengolahan Citra Digital, 2019

Sub-satuan bentuk lahan asal proses vulkanik mendominasi pada kondisi topografi bergelombang hingga berbukit dengan material penyusun batuan beku yang tersebar pada sisi
Barat Kabupaten Soppeng. Sub-satuan bentuk lahan asal proses struktural tersebar pada sisi Timur Kabupaten Soppeng dengan kondisi topografi berombak hingga bergelombang 
ditandai dengan adanya kontrol struktur geologi lipatan dan patahan yang bekerja dengan material penyusun batuan sedimen. Sub-satuan bentuk lahan asal proses fluvial terdapat pada sisi tengah Kabupaten Soppeng yaitu pada daerah datar hingga landai dengan material batuan sedimen hasil pengendapan material sungai. Sub-satuan bentuk lahan asal proses denudasional dan solusional (karst) terdapat pada sisi Selatan dengan kondisi topografi berombak hingga bergelombang dengan material batuan sedimen, persebaran sub-satuan bentuk lahan secara detail dapat dilihat pada Gambar 3.

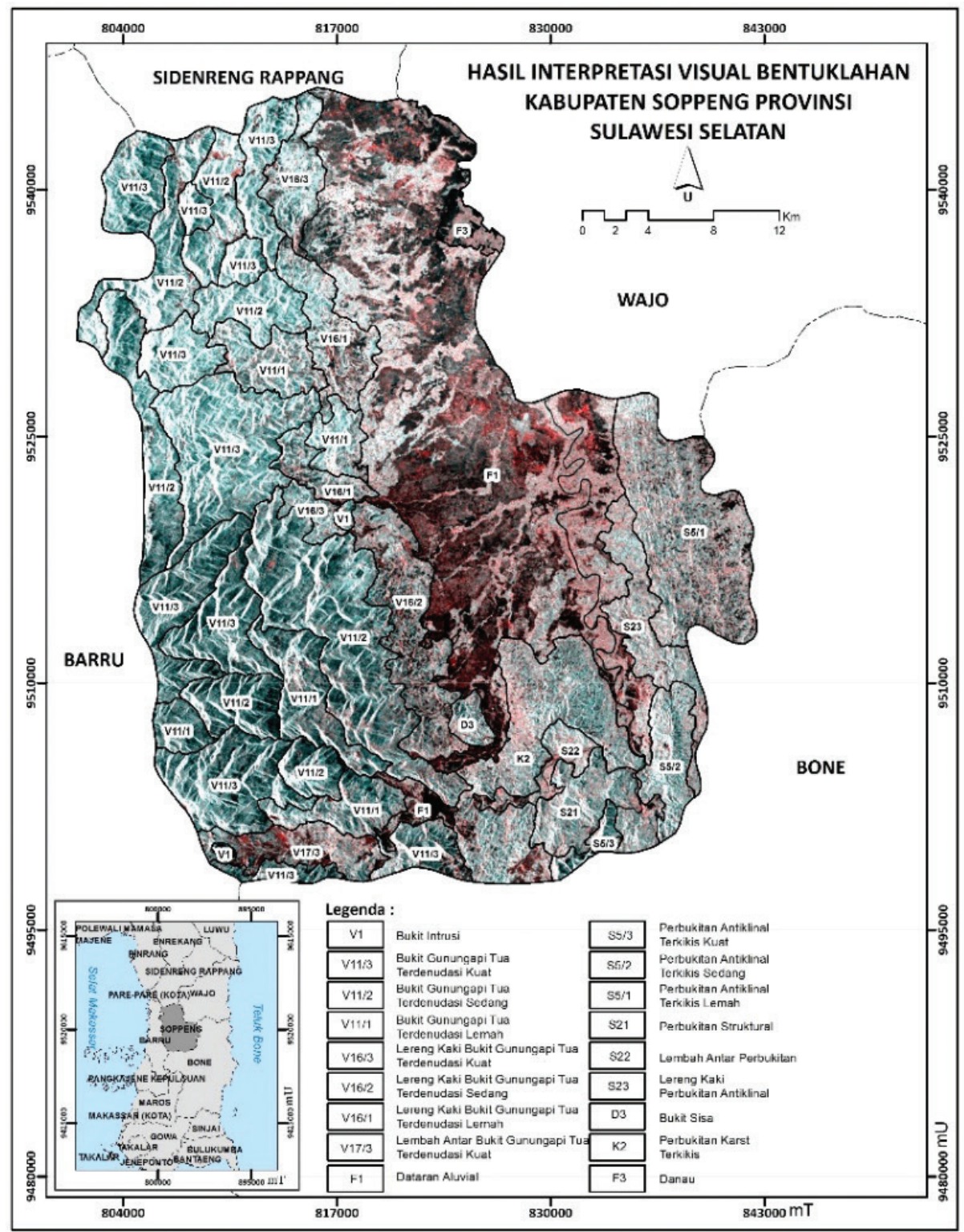

Gambar 3.

Hasil Interpretasi Bentuk lahan

Sumber: Analisis dan Pengolahan Citra Digital, 2019 


\section{Batuan (Litologi) dan Struktur Geologi Daerah Penelitian}

Identifikasi batuan (litologi) dilakukan dengan cara menurunkan informasi bentuk lahan. Setiap bentuk lahan memiliki informasi kondisi topografi, umur, intensitas proses, dan material utama penyusun bentuk lahan yang dapat menghasilkan informasi batuan (litologi). Struktur geologi diperoleh dengan melihat pola-pola kelurusan dan perubahan kondisi topografi yang tegas. Berdasarkan hasil analisis yang dilakukan, terdapat 12 kelas batuan (litologi) yang dapat diidentifikasi seperti pada Tabel 2.

Batuan beku intrusif merupakan material batuan paling dominan di daerah penelitian tersebar pada sisi Barat terdiri dari lava, breksi, konglomerat, trakit, dan sisipan tuff. Material batuan ini menunjukan adanya aktivitas magmatik gunung api tua sebagai indikator adanya mineral teralterasi hidrotermal. Batuan sedimen terdiri dari batu lempung, batu pasir, batu lanau, napal, batu gamping, dan endapan aluvium tersebar pada sisi Timur dan Selatan daerah penelitian. Struktur geologi dikenali berdasarkan informasi pola kelurusan dan perubahan kondisi topografi yang tegas. Berdasarkan interpretasi visual yang dilakukan terdapat empat struktur geologi yang dihasilkan yaitu kelurusan, antiklin, sesar, dan sesar geser yang tersebar pada sisi Timur dan Selatan. Detail persebaran jenis batuan dan struktur geologi dapat dilihat pada Gambar 4.

Tabel 2

Jenis Batuan dan Luasan Hasil Interpretasi

\begin{tabular}{l|l|l}
\hline \multicolumn{1}{c|}{ Kode } & \multicolumn{1}{c|}{ Batuan } & Luas $\left.\mathbf{( K m}^{\mathbf{2}}\right)$ \\
\hline BP & Batu Pasir & 6.234 \\
\hline BGN & Batu Gamping dan Napal & 75.635 \\
\hline BLT & Batu Lempung dan tufa & 30.287 \\
\hline AL & Aluvium (Kerikil, Pasir, Lempung) & 401.522 \\
\hline BGBL & Batu Gamping dan Batu Lempung & 28.216 \\
\hline BLBN & Batu Lempung dan Batu Lanau & 113.177 \\
\hline BPBL & Batu Pasir dan Batu Lempung & 35.331 \\
\hline BR & Breksi & 272.705 \\
\hline BK & Breksi dan Konglomerat & 95.312 \\
\hline LV & Lava & 110.311 \\
\hline LB & Lava dan Breksi & 77.312 \\
\hline LBT & Lava, Breksi dan Sisipan Tuff & 113.526 \\
\hline TR & Trakit & 2.803 \\
\hline Total Luas & & 1362.372 \\
\hline
\end{tabular}

Sumber: Analisis dan Pengolahan Citra Digital, 2019 


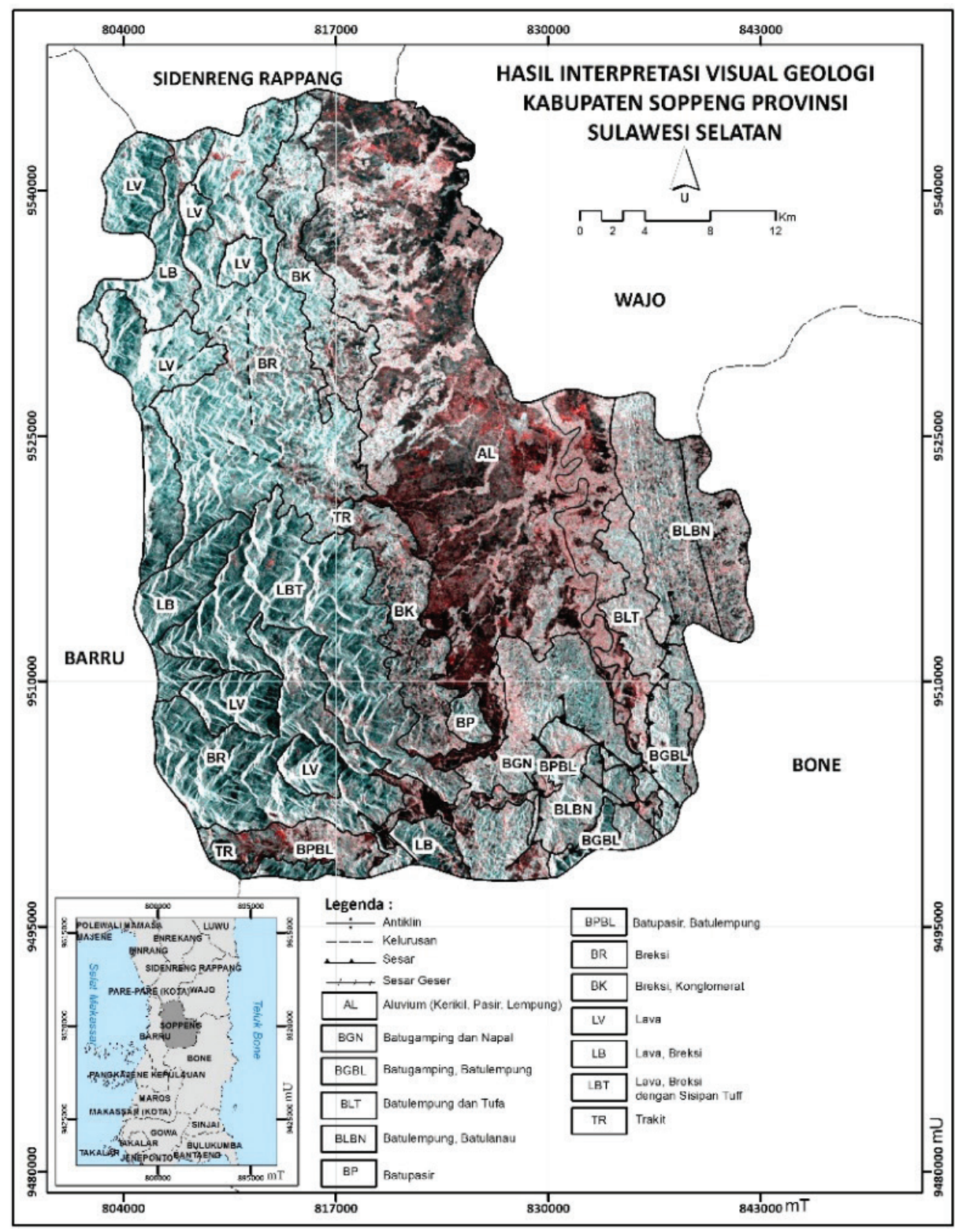

Gambar 4.

Hasil Interpretasi Batuan (Litologi) dan Struktur Geologi Sumber: Analisis dan Pengolahan Citra Digital, 2019

\section{Uji Akurasi}

Uji akurasi dilakukan untuk menilai akurasi hasil interpretasi bentuk lahan, batuan (litologi), dan struktur geologi terhadap data independen peta geologi skala 1:250.000. Subsatuan bentuk lahan yang memuat informasi kondisi topografi, umur, intensitas proses, dan material penyusun dikelompokkan menjadi kelas satuan medan yang lebih luas untuk dilakukan proses uji akurasi. Nilai akurasi total dari proses uji akurasi yang dilakukan pada Tabel 3 adalah 83,9\%. Nilai tersebut menunjukan bahwa hasil interpretasi citra ALOS-1 PALSAR multi-polarisasi HH, HV, HV yang dilakukan baik dan cukup sesuai dengan kondisi di lapangan. 
Tabel 3

Uji Akurasi Confusion Matrix Hasil Interpretasi

\begin{tabular}{|c|c|c|c|c|c|c|c|}
\hline & \multicolumn{6}{|c|}{ Informasi Peta Geologi } \\
\hline & & $\begin{array}{c}\text { Formasi Gunung api } \\
\text { Soppeng (Tmsv); } \\
\text { Terobosan }(\mathrm{T}) ; \\
\text { Camba (Tmcv) }\end{array}$ & $\begin{array}{l}\text { Formasi } \\
\text { Walanae } \\
\text { (Tmpw) }\end{array}$ & $\begin{array}{l}\text { Formasi Tonasa } \\
\text { (Temt); Anggauta } \\
\text { Tacipi Walanae } \\
\text { (Tmpt) }\end{array}$ & $\begin{array}{c}\text { Formasi } \\
\text { Malawa } \\
\text { (Tem) }\end{array}$ & $\begin{array}{l}\text { Endapan } \\
\text { Aluvium } \\
\text { (Qac) }\end{array}$ & $\begin{array}{l}\text { Total } \\
\text { Baris }\end{array}$ \\
\hline \multirow{5}{*}{ 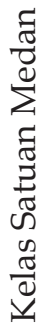 } & Satuan Medan A & 1019 & 25 & 39 & 16 & 2 & 1101 \\
\hline & Satuan Medan B & 0 & 228 & 52 & 0 & 7 & 287 \\
\hline & Satuan Medan C & 0 & 73 & 38 & 0 & 3 & 114 \\
\hline & Satuan Medan D & 0 & 0 & 0 & 9 & 1 & 10 \\
\hline & Satuan Medan E & 33 & 88 & 6 & 0 & 505 & 632 \\
\hline \multicolumn{2}{|c|}{ Total Kolom } & 1052 & 414 & 135 & 25 & 518 & 2144 \\
\hline
\end{tabular}

Total Akurasi: $(1799 / 2144) \times 100 \%=83,9 \%$

Sumber : Analisis dan Pengolahan Citra Digital, 2019

Nilai omission dan commission berdasarkan Tabel 4 menunjukan bahwa satuan medan E yang terdiri dari bentuk lahan asal proses fluvial memiliki nilai akurasi pembuat paling tinggi yaitu $97,49 \%$. Nilai akurasi tersebut meunjukan bahwa bentuk lahan asal proses fluvial dapat dikenali dengan baik oleh pembuat peta berdasarkan citra yang digunakan. Satuan medan A memiliki nilai akurasi paling tinggi pada pengguna peta yaitu $92,55 \%$ yang terdiri dari bentuk lahan asal proses vulkanik dengan material batuan beku intrusi. Satuan medan $\mathrm{C}$ memiliki nilai akurasi paling rendah pada akurasi pembuat maupun pengguna peta yaitu 28,14\% dan 33,33\% yang terdiri dari sub satuan bentuk lahan perbukitan karst terkikis berbatuan batugamping dan napal. Nilai tersebut menunjukan bahwa satuan medan C sulit untuk dikenali dari citra ALOS-1 PALSAR multi-polarisasi $\mathrm{HH}, \mathrm{HV}, \mathrm{HV}$ maupun peta yang dihasilkan dari interpretasi visual citra.

Tabel 4

Omission dan Commission Hasil Interpretasi

\begin{tabular}{l|l|l|l|l}
\hline \multirow{2}{*}{ Kelas Satuan Medan } & \multicolumn{2}{c|}{ Producer Accuracy } & \multicolumn{2}{c}{ User Accuracy } \\
\cline { 2 - 5 } & \multicolumn{1}{|c}{ Accuracy } & \multicolumn{1}{c}{ Omission } & \multicolumn{1}{c}{ Accuracy } & \multicolumn{1}{c}{ Commission } \\
\hline Satuan Medan A & 96,86 & 3,14 & 92,55 & 7,45 \\
\hline Satuan Medan B & 55,07 & 44,93 & 79,44 & 20,56 \\
\hline Satuan Medan C & 28,14 & 71,86 & 33,33 & 66,67 \\
\hline Satuan Medan D & 36 & 64 & 90 & 10 \\
\hline Satuan Medan E & 97,49 & 2,51 & 79,90 & 20,10 \\
\hline
\end{tabular}

Sumber: Analisis dan Pengolahan Citra Digital, 2019

\section{Zonasi Mineral Alterasi Hidrotermal}

Zonasi mineral alterasi hidrotermal ditentukan berdasarkan informasi satuan medan dan hasil analisis mineral petrografi laboratorium. Hasil analisis laboratorium sangat penting untuk melihat kandungan mineral batuan yang ada pada tiap satuan medan daerah penelitian. Setiap jenis alterasi akan memiliki karakteristik mineral (mineral indeksi) yang berbeda-beda sesuai dengan proses dan material pembentukannya (Corbett \& Leach, 1996). Alur penentuan zona mineral alterasi hidrotermal dapat dilihat pada Gambar 5 . 


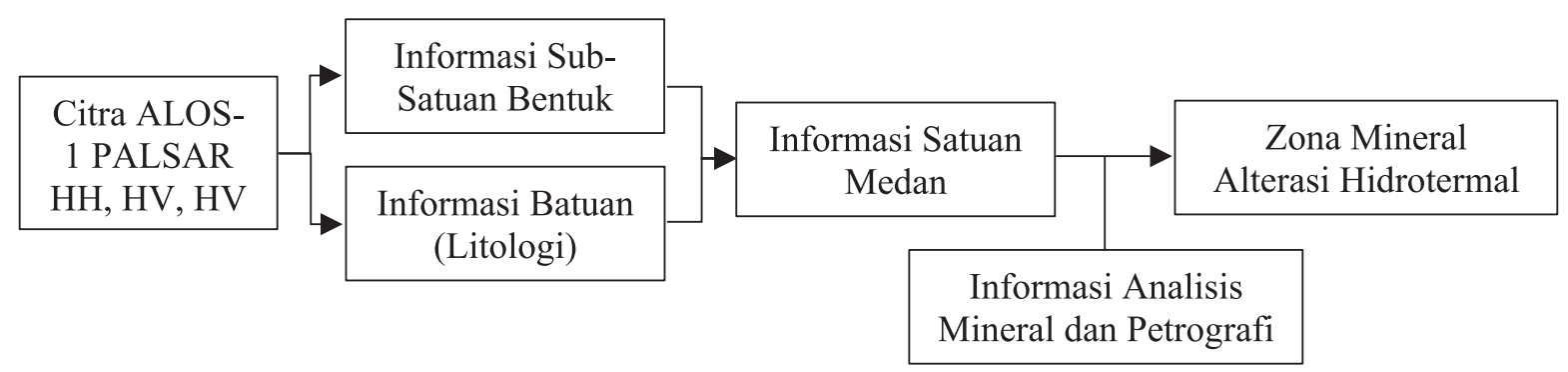

Gambar 5.

Alur Penentuan Zona Mineral Alterasi Hidrotermal Sumber: Analisis dan Pengolahan Citra Digital, 2019

Zona alterasi hidrotermal yang dapat diidentifikasi berdasarkan analisis satuan medan dan analisis mineral petrografi adalah zona alterasi argilik, argilik sempurna, filik, potasik, propilitik, sub propilitik, dan skarn. Zona alterasi argilik ditentukan dengan munculnya mineral lempung pada material batuan (Gambar 6-a). Selain mineral lempung, terdapat juga mineral penyerta seperti fosil, opak, fragmen litik, dan kalsit. Zona alterasi argilik dapat ditemui pada daerah dengan kondisi topografi datar hingga bergelombang dengan material batuan sedimen.

Zona alterasi argilik sempurna dapat dikenali dengan munculnya mineral indeks kaolin dan kuarsa (Gambar 6-b). Selain mineral indeks terdapat mineral penyerta seperti mineral serisit, epidot, klorit, dan mineral opak. Zona mineral alterasi ini terdapat pada daerah dengan kondisi topografi bergelombang hingga berbukit. Tipe mineral alterasi ini ditemui pada jenis batuan breksi gunung api tua.

Zona alterasi filik dikenali dengan adanya mineral utama batuan yaitu kuarsa dan mika (Gambar 6-c). Selain kandungan mineral utama juga di dampingi mineral penyerta plagioklas, olivin, piroksen, feldspar dan opak. Zona mineral filik terdapat pada daerah sub satuan bentuk lahan lereng gunung api tua terdenudasi. Daerah lereng gunung api memiliki material batuan beku breksi gunung api dengan kandungan mineral tersebut.

Zona alterasi potasik ditandai dengan munculnya mineral indeks kuarsa dan feldspar dengan persentase besar (Gambar 6-d). Selain mineral indeks tersebut, ada juga mineral penyerta seperti plagioklas, amfibol, epidot, opak, piroksen, dan massa dasar. Zona mineral alterasi ini ditemui pada daerah dengan kondisi topografi berbukit dan daerah intrusi. Material batuan penyusun mineral ini yaitu breksi dan trakit.

Zona alterasi propilitik ditandai dengan munculnya mineral indeks klorit, kuarsa, dan epidot (Gambar 6-e). Selain mineral utama terdapat juga mineral penyerta seperti plagioklas, amfibol, opak, piroksen, fragmen litik, lempung karbonat, lempung silika, dan massa dasar. Mineral alterasi ini dijumpai pada daerah dengan kondisi topografi berbukit dan intensitas erosi sedang hingga tinggi. Jenis mineral ini terdapat pada jenis batuan lava gunung api tua dan breksi gunung api tua.

Zona alterasi sub propilitik dapat diidentifikasi berdasarkan kemunculan mineral indeks berupa lempung karbonat dan klorit dengan persentase besar (Gambar 6-f). Selain itu terdapat mineral penyerta seperti kuarsa, kalsit, opak, piroksen, olivin, dan massa dasar. Zona alterasi sub propilitik dijumpai pada daerah dengan kondisi topografi berbukit dan intensitas erosi lemah hingga sedang. Mineral ini terdapat pada jenis batuan beku intrusif gunung api.

Zona alterasi skarn memiliki ciri khas yaitu hadirnya mineral indeks berupa kuarsa dan kalsit dengan persentase besar tergolong dalam grup kalk-silika (Gambar 6-g). Selain mineral indeks, terdapat juga mineral penyerta seperti fragmen litik, lempung - 
lempung karbonat, dan opak. Zona mineral ini dapat dijumpai pada daerah dengan kondisi topografi berombak hingga bergelombang dengan material utama batugamping.

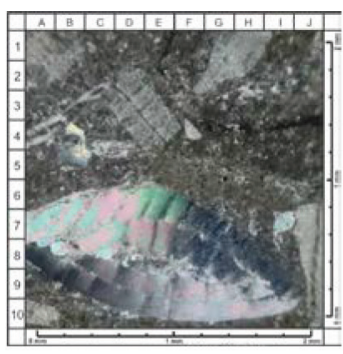

a.

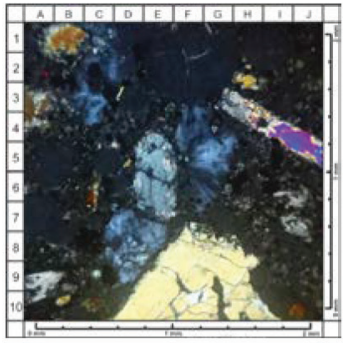

e.

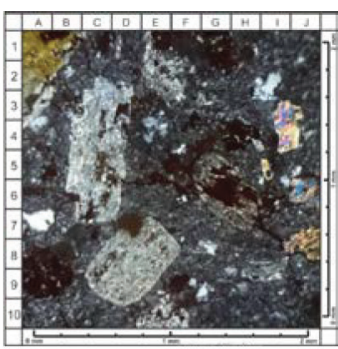

b.

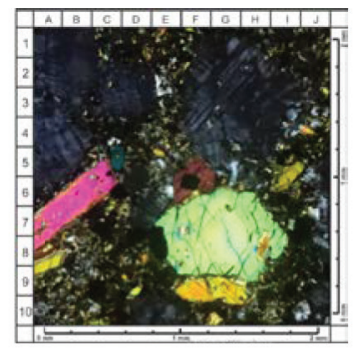

c.

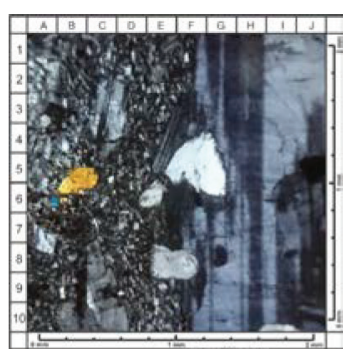

d.

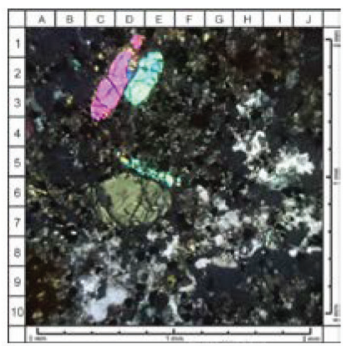

f.

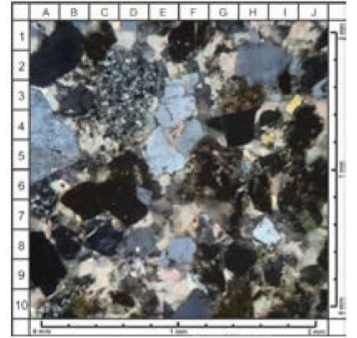

g.

Gambar 6.

Hasil Analisis Mineral dan Petrografi Tiap Zona Alterasi Sumber: Analisis Mineral dan Petrografi, 2019

Klasifikasi zona alterasi hidrotermal dan parameter satuan medan dari citra dapat digunakan untuk mengetahui persebaran zona alterasi hidrotermal di daerah penelitian seperti pada Gambar 7. Hasil analisis pada Tabel 5 menunjukkan bahwa zona alterasi propilitik mendominasi di Kabupaten Soppeng dengan luas $328,746 \mathrm{~km}^{2}$, sedangkan luas zona argilik sempurna paling sempit yaitu 20,239 $\mathrm{km}^{2}$.

Tabel 5

Tipe dan Luasan Zona Alterasi Hidrotermal

\begin{tabular}{l|l}
\hline \multicolumn{1}{c|}{ Zona Alterasi } & \multicolumn{1}{c}{ Luas $\left.\mathbf{( K m}^{2}\right)$} \\
\hline Non Alterasi & 393,105 \\
\hline Argilik & 221,662 \\
\hline Argilik Sempurna & 20,239 \\
\hline Filik & 94,790 \\
\hline Potasik & 46,678 \\
\hline Propilitik & 328,746 \\
\hline Sub Propilitik & 181,517 \\
\hline Skarn & 75,635 \\
\hline Total & $\mathbf{1 3 6 2 , 3 7 2}$ \\
\hline
\end{tabular}

Sumber: Analisis dan Pengolahan Citra Digital, 2019 


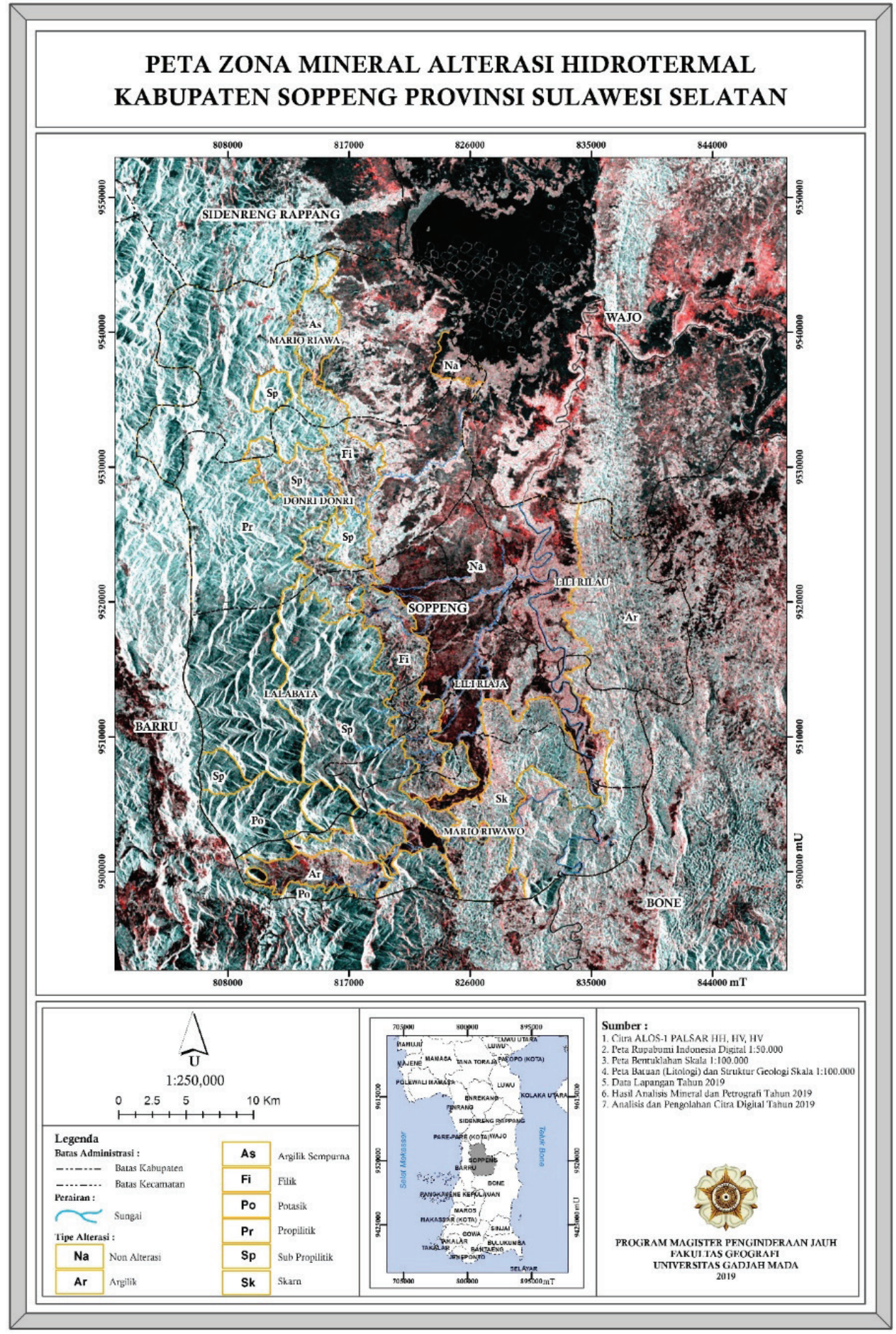

Gambar 7.

Peta Zona Alterasi Hidrotermal Kabupaten Soppeng Sumber: Analisis dan Pengolahan Citra Digital, 2019 
Zona mineral alterasi argilik tersebar pada sisi Timur Kabupaten Soppeng dengan dominasi bentuk lahan asal proses struktural yang dikontrol oleh lipatan dan patahan. Zona mineral alterasi argilik sempurna terdapat pada sisi Utara dengan bentuk lahan lereng kaki gunung api tua terdenudasi kuat dengan material batuan breksi gunung api. Zona mineral alterasi filik didominasi pada daerah lereng kaki bukit gunung api tua terdenudasi lemah hingga sedang pada sisi tengah Kabupaten Soppeng. Zona mineral alterasi potasik terdapat pada sisi Selatan dengan material batuan beku intrusi pada daerahdaerah bentuk lahan intursi gunung api. Zona mineral alterasi propilitik dan sub-propilitik terdapat pada sisi Barat Kabupaten Soppeng dengan bentuk lahan bukit gunung api tua terdenudasi dengan material batuan beku.

\section{SIMPULAN}

Radar multi-polarisasi dapat digunakan untuk meningkatkan visualisasi citra. Kombinasi polarisasi $\mathrm{HH}, \mathrm{HV}, \mathrm{HV}$ pada citra ALOS-1 PALSAR memiliki kemampuan yang baik untuk identifikasi parameter bentuk lahan, batuan (litologi), dan struktur geologi ditandai dengan nilai total akurasi $83,9 \%$. Kondisi topografi, batas perubahan topografi, dan pola-pola kelurusan dapat dikenali dengan baik dan jelas.

Zona alterasi hidrotermal di Kabupaten Soppeng terdiri dari zona alterasi argilik, argilik sempurna, filik, potasik, propilitik, sub propilitik, dan skarn. Zona alterasi propilitik merupakan zona alterasi paling luas yaitu $328,746 \mathrm{Km}^{2}$ tersebar pada daerah topografi berbukit dengan material batuan beku intrusif. Zona alterasi argilik sempurna merupakan zona alterasi paling sempit dengan luas $20,239 \mathrm{Km}^{2}$ tersebar pada daerah topografi bergelombang dengan material batuan breksi gunung api.

\section{DAFTAR PUSTAKA}

Carranza, E. J. (2002). Geologically-Constrained Mineral Potential Mapping: Examples from the Philippines. Enschede: ITC.

Corbett, G. J. dan Leach, T. M. (1996). Southwest Pacific Rim Gold/Copper System: Structure, Alteration, and Mineralization, in Society of Exploration Geochemist. Townville, p. 145.

Pour, A. B. dan Hashim, M. (2014). Structural geology mapping using PALSAR data in the Bau gold mining district , Sarawak , Malaysia.' Advances in Space Research. COSPAR, 54 (4): 644654.

Spatz, D. (1997). Remote Sensing Characteristics of the Sediment - and Volcanic-Hosted Precious Metal System: Imagery Selection for Exploration and Development, Journal Remote Sensing, (18): 14131438.

Ulaby, F. T., Moore, R. K. dan Fung, A. K. (1986). Microwave Remote Sensing Active and Passive: From Theory to Applications. United States: Addison Wesley.

Verstappen, H. T. (2000). The Geomorphologi of Indonesia. The Netherland: ITC.

Zandbergen, P. (2008). Application of Shuttle Radar Topography Mission Elevation Data', Geography Compass 2, (5): 1404-1431. 